\title{
LIFE SKILLS EDUCATION IN INCREASING THE INDEPENDENCE OF STUDENTS PURSUING PACKAGE C THROUGH THE SPNF SKB TRENGGALEK
}

\author{
Oleh \\ Suwarnoto $^{1)}$, Hikmah Eva Trisnantari ${ }^{2)}$ \& Imam Suwaktus Su'jai ${ }^{3)}$ \\ 1,2,3 Universitas Bhinneka PGRI \\ Email: ${ }^{1}$ otosuwarnoto@gmail.com, ${ }^{2}$ hikmaheva@ gmail.com \& ${ }^{3}$ doktorsujai@ gmail.com
}

\begin{abstract}
The background of the research in this thesis is based on population data in Trenggalek district, it is found that the population of productive age with low education (not graduating from school) has an unemployment rate that is higher than those who have completed education. The research focuses in this thesis are: (1). How is the personal skills ordering system in increasing the independence of package C students at SPNF SKB Trenggalek (2). How is the social skills booking system in increasing the independence of package $\mathrm{C}$ students. (3). What is the system for ordering intellectual skills in increasing the independence of package $C$ students (4). How is the vocational proficiency ordering system in increasing the independence of package $\mathrm{C}$ students. The results of the research are (1). The personal skill formation system in increasing the independence of package $\mathrm{C}$ students at SPNF SKB Trenggalek is a very important skill, even the first and foremost skill that students must have, where personal skills are behaving in accordance with religious, social, and religious norms. law, have faith in God Almighty, have noble character, are just, honest, commendable, have a work ethic, are responsible and can be trusted. (2).Social skills formation system in increasing the independence of package $\mathrm{C}$ students: Social skills for students have characteristics, namely being open, easy to socialize / communicate well with others, superiors, customers / customers and relate to their environment / community the surroundings. (3). The system for building intellectual skills in increasing the independence of package $\mathrm{C}$ students: Where this skill implies the ability to analyze simply, think logically, the ability to make decisions, explore good ideas, the ability to dare to try in their field scientifically . (4). Vocational skills formation system in increasing the independence of package C students: Vocational skills (vocational skills), namely the ability to choose jobs, job training, mastering competencies, mastering skills, applying technology, carrying out work processes and producing goods and services that can ultimately improve their standard of living and be able to compete with DU / DI.
\end{abstract}

Keywords: Students, Package C \& Nonformal

1.

\section{PENDAHULUAN}

Program Pendidikan non formal yang berfungsi sebagai : penambah, pengganti, pelengkap dengan menitik beratkan pada penguasaan pengetahuan dan ketrampilan fungsional, sikap dan kepribadian professional, sehingga diharapkan warga belajar setelah mengikuti pembelajaran dapat menguasai ketrampilan sesuai dengan bakat dan minat peserta didik sehingga nanti setelah lulus sekolah di program paket C bisa mengembangkan ketrampilanya di masyarakat yang dapat mendatangkan penghasilan bagi diri sendiri dan keluarganya.

Para peserta didik disamping membutukan pengetahuan secara akademik, tidak kalah pentingnya adalah bekal ketrampilan yang relevan dengan lingkungan masyarakat / DUDI agar peserta didik dapat langsung bekerja sesuai dengan ketrampilan yang dimiliki selama mengikuti Pendidikan yang disebut Pendidikan kecakapan hidup atau life skill. 
Tujuan penyelenggaraan Program kecakapan hidup/ life skill sebagai berikut: 1 . Memberikan bekal pengetahuan, keterampilan, sikap dan pola piker berwirausaha melalui kursus dan pelatihan kepada peserta didik. 2 . Memotivasi dan menciptakan rintisan usaha baru serta pendampingan untuk dapat berkembang dan mampu bermitra dengan dunia usaha dan dunia industri serta instansi terkait.

Perhatian pemerintah pusat melalui Direktorat Pendidikan Masyarakat dan Direktorat Kursus dan Pelatihan terhadap Pendidikan non formal sangat besar terbukti mulai tahun 2009 Program - Program Pendidikan Non Formal mulai dari PAUD, Keaksaraan, Kursus dan Program Kesetaraan Paket A,B dan Paket C Telah dibiayai oleh Pemerintah pusat . Jadi bagi masyarakat / warga belajar yang mengikuti program tersebut diatas tidak dipungut biaya atau gratis .Dengan harapan masyarakat yang usia produktif (16-40 th ) terutama yang kurang mampu termasuk peserta didik paket $\mathrm{C}$ selain memperoleh ijazah Paket C setara SMA juga memperoleh ketrampilan dan bekal hidup / life skill yang nantinya diharapkan bisa memperoleh pekerjaan bahkan bisa membuka usaha sendiri / berwiraswasta.

Menurut peneliti selaku Pendidik / Pamong Belajar sekaligus sebagai Kepala SPNF SKB Kabupaten Trenggalek antara tujuan Pemerintah membiayai program program Pendidikan Non Formal terutama Program LIFE SKILL, Kesetaran Paket A. B dan paket C di SPNF SKB Trenggalek ternyata kurang berhasil terbukti setelah lulus dari Paket C dan mengikuti program life skill bidang computer . menjahit/ tata busana . tata rias atau tata boga masih banyak yang menganggur / melanjutkan sekolah yang lebih tinggi Menurut peneliti berdasarkan data kependudukan di kabupaten trenggalek diperoleh bahwa mayoritas penduduk usia produktif yang berpendidikan rendah (tidak lulus sekolah) memiliki tingkat pengangguran yang lebih dibandingkan dengan yang telah selesai menempuh jenjang Pendidikan.
Berdasarkan uraian latar belakang tersebut diatas, maka penelitian ini dilaksanakan dengan judul Pendidikan kecakapan hidup (life skill) dalam meningkatkan kemandirian peserta didik kejar paket C melalui di SPNF SKB Trenggalek.

Fokus penelitian dalam tesis ini adalah:

(1). Bagaimana sistem pembentukan kecakapan personal dalam meningkatkan kemandirian peserta didik paket $\mathrm{C}$ di SPNF SKB Trenggalek (2).Bagaimana sistem pembentukan kecakapan social dalam meningkatkan kemandirian peserta didik paket C (3). Bagaimana sistem pembentukan kecakapan intelektual dalam meningkatkan kemandirian peserta didik paket $\mathrm{C}$ (4).Bagaimana sistem pembentukan kecakapan vokasional dalam meningkatkan kemandirian peserta didik paket $\mathrm{C}$.

\section{METODE PENELITIAN}

Berdasarkan masalah dan tujuan penelitian, jenis penelitian ini merupakan penelitian deskriptif kualitatif. Populasi dalam penelitian ini adalah seluruh siswa Tata Boga kelas X sebanyak 70 siswa, Sampel yang digunakan dalam penelitian ini adalah siswa kelas X Tata Boga 1 sebanyak 35 orang. Teknik pengumpulan data yang digunakan dapat dilakukan dengan cara: observasi (pengamatan), wawancara (interview), dan dokumentasi atau gabungan semuanya.

\section{HASIL DAN PEMBAHASAN}

Sistem pembentukan kecakapan personal dalam meningkatkan kemandirian peserta didik paket C di SPNF SKB Trenggalek merupakan kecakapan yang sangat penting bahkan merupakan kecakapan pertama dan utama yang harus dimiliki oleh peserta didik, dimana kecakapan personal adalah berperilaku sesuai dengan norma agama , social, hukum , beriman kepada Tuhan Yang Maha Esa, beraklak mulia, adil, jujur, terpuji, memiliki etos kerja, tanggung jawab dan dapat dipercaya.

Masalah pembentukan kecakapan personal ini sesuai dengan hasil wawancara 
kami dengan Guru atau Pamong Belajar yang ada di SPNF SKB trenggalaek merupakan tantangan / tugas yang sangat berat dikarenakan input dari peserta didik paket $\mathrm{C}$ yang sangat majemuk ditnjau dari segi usia, latar belakang .keluarga dan sosial ekonominya , letak geografis yang jauh dari sekolah formal tingkat SLTA.

Sistem pembentukan kecakapan sosial dalam meningkatkan kemandirian peserta didik paket C di SPNF SKB Trenggalek. Kecakapan sosial bagi peserta didik mempunyai ciri -ciri yaitu bersikap terbuka , mudah bergaul/ berkomunikasi baik dengan sesame, atasan , customer/ pelanggan dan berhubungan dengan lingkungannya/ masyarakat sekitarnya.

Kecakapan berkomunikasi dapat dilakukan secara lisan maupun tulisam , kemampuan mendengarkan dan menyampaikan gagasan secara lisan maupun tulisan perlu dikembangkan. Kecakapan mendengarkan dengan empati akan membuat orang mampu memahami isi pembicaraan orang lain, sementara lawawan bicaramerasa diperhatikan dan dihargai

Sistem pembentukan kecakapan intelektual dalam meningkatkan kemandirian peserta didik paket C di SPNF SKB Trenggalek. Dimana kecakapan ini mengandung makna kemampuan menganalisa sederhana, berfikir dengan logika, kemampuan mengambil keputusan, menggali ide - ide yang baik, kemampuan untuk berani mencoba dibidangnya secara ilmiah.

Sistem pembentukan kecakapan vokasional dalam meningkatkan kemandirian peserta didik paket $\mathrm{C}$ di SPNF SKB Trenggalek. Diatas kecakapan vokasinal sangatlah penting, karena sangat pentingnya Menteri Pendidikan dan Kebudayaan RI Nadiem Makarim membentuk direktorat khusus Vokasi dengan tujuan masyarakat usia produktif antara 16-35 tahun bisa terlayani dari program - program Vokasi secara gratis termasuk bagi peserta didik paket C. melalui satuan Pendidikan baik formal seperti SMK, Politeknik Dan nonformal seperti SPNF SKB, PKBM ( Pusat Kegiatan Belajar Masyarakat ) dan LKP ( Lembaga Kursus dan Pelatihan ). Kecakapan hidup Vokasional (vocasional skill ) yaitu kecakapan memilih pekerjaan, pelatihan kerja, penguasaan kompetensi, menguasai ketrampilan, menerapkan teknologi , melaksanakan proses pekerjaan dan menghasilkan produk barang dan jasa yang akirnya bisa meningkatkan taraf hidupnya dan mampu bersaing dengan DU/DI. Kecakapan Vokasional adalah ketrampilan yang dikaitkan dengan berbagai bidang pekerjaan tertentu yang terdapat di masyarakat. Kecakapan vokasional mencakup kecakapan vokasional dasar ( basic vokasional skill ) dan kecakapan vokasional khusus ( accupational skill ).

Kecakapan vokasional dasar yang berkaitan dengan bagaimana peserta didik menggunakan alat sederhana missal obeng , palu dan sebagainya.

Kecakapan vokasional khusus hanya diperlukan bagi merekayang akan menekuni pekerjaan yang sesuai dengan bidangnya missal pekerjaan montir,apoteker, tukang dan sebagainya.

\section{PENUTUP}

\section{Kesimpulan}

Sistem pembentukan kecakapan personal dalam meningkatkan kemandirian peserta didik paket C di SPNF SKB Trenggalek merupakan kecakapan yang sangat penting bahkan merupakan kecakapan pertama dan utama yang harus dimiliki oleh peserta didik, dimana kecakapan personal adalah berperilaku sesuai dengan norma agama , social, hukum , beriman kepada Tuhan Yang Maha Esa, beraklak mulia, adil, jujur, terpuji, memiliki etos kerja, tanggung jawab dan dapat dipercaya.

\section{DAFTAR PUSTAKA}

[1] Depdikbud. (2013). Materi pelatihan guru implementasi kurikulum 2013 SMP, MTs Ilmu Alam (pp.1-366). Jakarta: Badan Pengembangan Sumber Daya Manusia Pendidikan dan Kebudayaan dan Penjaminan Mutu Pendidikan, Kemendikbud. 
[2] Hamm, R.W. (1985). A Systematic evaluation of an environmental invertigation course.(Doctoral dissertation.Georgia State University). ERIC Document. Repro-duction Service No ED-256-622.

[3] Paramata, Y. (2001). Pengembangan model so-sialisasi inovasi dan supervisi pembelajaran ilmupengetahuan alam. (Disertasi Dok-tor. Universitas Pendidikan Indone-sia). Hal 2.

[4] Provus, M., Malcolm. (1969). The discrepancy evaluation models. An approach to local program improvement and development. Pitaburgh Public School.

[5] Raharja, J. T., \& Retnowati, T. H. (2013). Evaluasi Pelaksanan Pembelajaran Seni Budaya SMA di Kabupaten Lombok Timur, NTB.Jurnal Penelitian dan Evaluasi Pendidikan. Vol. 17, No. 2, (pp.287-258).

[6] Rustaman, N.Y. (2010). Kemampuan Dasar Bekerja Ilmiah dalam Pendidikan Sains dan Asessmentnya. Makalah Universitas

Indonesia.http://file.upi.edu/direktori/sps/ prodi.pendidikan_ipa/195012311979032_ nuryani_rustaman/kdbi_dalamdiksainsfina 1.pdf (diakses 08 April 2014)

[7] Scriven, M. (1967). The methodology of eva-luation.In R.W.Tyler.R M. Gagne, \& M Scriven (Eds).Perspectrives of curriculum evaluation. (pp.39-83). Chicago: Rand McNally.

[8] Stake, R E. (1967). Forward technology for the evaluation of educational programs. In R W Tyler, R M Gagne, \& M Scriven. (Eds). Perpectives of curriculum evaluation. (pp.1-12). Chicago: Rand McNally.

[9] Stake, R E. (1967). The countenance of educational evaluation. Teacher's Coolege Record. Vol. 68, no:7.

[10] Stake, R E. (1977).The Countenance of edu-cational evaluation.In A.A. Bellack \& H.M Kliebard. Eds 1. Curriculum and evaluation (pp. 372-390).Berkeley.CA McCutehan.
[11] Stufflebeam, D. L., \& Shinkfield, A.J. (1984). Systematic evaluation a selfinstructional guide to theory and practice. Boston: Kluwer-Nijhoff Publishing. 